PAH Labuschagne

Professor and Former Chair, Department of Political Sciences, College of Human Sciences, University of South Africa. E-mail: labuspah@unisa.ac.za

DOI: https://dx.doi. org/10.18820/24150509/ JCH42.v2.6

ISSN 0258-2422 (Print) ISSN 2415-0509 (Online) Journal for Contemporary History

2017 42(2):127-142

(C) UV/UFS

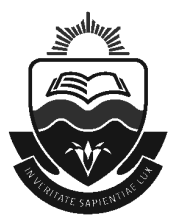

\section{CROSSING THE RACIAL DIVIDE: THE 1946 RHODES UNIVERSITY VERSUS FORT HARE UNIVERSITY ATHLETICS MEETING}

\begin{abstract}
In the annals of South Africa's sporting history, the intervarsity athletics meeting between Rhodes University and the University of Fort Hare that took place in 1946 is not well-known. This encounter between two neighbouring universities is unique for a number of reasons: not only was it the first reported athletics meeting at club level between two universities in the Eastern Cape, it was also the first time in South Africa that different race groups competed at club level. The meeting flouted the government's policies at that time, as well as its stated position on the segregation of the different race groups. In the article the broad background of segregation in South Africa is outlined, with a description of how clubs developed in keeping with segregationist policies. The historic meeting between the universities of Rhodes and Fort Hare is the focus of the second part of the discussion, which demonstrates how athletics officials at Rhodes were prepared to challenge national policies in an attempt to further racial harmony. The historic athletics meeting between the two universities was a brave effort to normalise society and reflected an enlightened approach to the prevailing segregationist policies being imposed on all levels of society.
\end{abstract}

Keywords: Athletics; Fort Hare University; racial hegemony; Rhodes University; segregation.

Sleutelwoorde: Atletiek; Fort Hare Universiteit; rassehegemonie; Rhodes Universiteit; segregasie.

\section{INTRODUCTION}

In the annals of the history of sport a solitary incident has the political potential to form a seminal moment. The effect could be so dramatic that it conceivably shapes the socio-political contours and development of a country. There are multiple examples in international and domestic sport of high-impact events that reverberated into the political domain. One such example was the political statement made by two 400 metre athletes from the United States (US), Tommy Smith and John Carlos, at the 1968 Olympic Games in Mexico. Smith and Carlos showed 
their defiance towards the US government and their national flag when during the medal ceremony, as medal winners, they raised their clenched, black-gloved fists skyward in a black power salute while the American national anthem was playing. This act of insolence on the part of the two black athletes was intended to show their solidarity with the black civil rights movement in the US (Wallechinsky 1984:115).

During the apartheid era in South Africa, the relationship between sport and politics was hallmarked by the perpetual interference of the latter. The history of sport under the apartheid regime has a chequered past, with its social contours continuously shaped and altered by the volatility of political events. One such watershed incident occurred in the 1960s when the then Prime Minister, John Vorster, withdrew an invitation to the Marylebone Cricket Club (MCC) team to tour South Africa. The reason behind this politically driven decision was the fact that the MCC team included a player of colour, the former South African, Basil D'Oliveira. His inclusion was not acceptable to the Pretoria regime with its track record of racial discrimination in sport (Arlott 1968:85).

Vorster's political decision had international ramifications, not only for cricket in South Africa, but for the international acceptance of the country's sportsmen and women in general. The ruling National Party's politically motivated decision formed a pivotal point that saw the country descend into a protracted period of boycotts and, subsequently, international isolation. During the apartheid era sporting codes and officials were largely at the mercy of politicians who exploited and plundered sport for their own ulterior motives (Allison 1986:115). ${ }^{1}$

Nonetheless, amidst the woeful tale of political interference in South African sports, there is evidence of courageous individuals within civil society who were

1 The interrelationship between sport and politics has been the topic of multiple authors. The importance of sport to politicians relates to geostationary satellite transmission which propelled sport into the global arena (Houlihan 1997:2). In the last few decades, large volumes were published on a variety of topics regarding the relationship between sport and politics. L Allison (2005) and A Bairner (2005) published on the topic of prestige and the power of groups in sport. Publications on the relationship between sport and politics cover a broad spectrum of topics, such as the use of sport for military preparedness (Coakley (2002) and Hartmann (2006)) and the promotion of identity and unity through sport (Allison (2005) and Bairner (2005)). In South Africa, political regulatory control in sport is also a topic addressed by multiple scholars in the field. A Grundlingh (1995) wrote on the importance of political power within the Afrikaner community and rugby. J Nauright and D Booley (1998) also addressed the issue of rugby in their publication on the South African nation, sport, culture and politics, and sport in the old and new South Africa. The interference of politics in cricket was addressed by Nauright and D Vahed (2009) in the seminal publication of $\mathrm{H}$ Murray and D Vahed (eds), The Empire and cricket: The South African experience, 1884-1914. C Korr and M Close (2008) addressed the interrelationship between politics and soccer in their publication, More than just a game: Soccer versus apartheid. 
prepared to challenge the sports policies of the government. This defiance mainly took place within a smaller and more restricted context, but showed a preparedness to confront the regime on its sporting policies. They do not form watershed events as such, but incidents of defiance. One such noteworthy incident was an historic inter-institutional athletics meeting that challenged race-based policies as it took place between a white university, Rhodes, and a black university, Fort Hare. Interestingly, this groundbreaking meeting, held on 23 October 1946 at St Matthew's College Stadium in the Eastern Cape, featured many people of colour who would later become notable black statesmen and politicians. ${ }^{2}$

Despite the pioneering efforts of civil society in the face of, what became a drawn-out, adverse relationship between sports officials and politicians in South Africa, the Rhodes-Fort Hare intervarsity meeting has largely slipped into historical oblivion. Yet, the intervarsity meeting which took place across the racial divide was a remarkable event at that time, manifesting the courage and commitment of individuals who desired change and were prepared to challenge racial discrimination to achieve it. The meeting remains a thought-provoking anecdote of resolute officials who were prepared to undermine government imposed racial conventions and, through sport, to test the resolve of national policy-makers set on segregating the races.

The significance of this athletics meeting in 1946 was that it was the first recorded official athletic competition in South Africa at club and national level across racial lines. The meeting took place within the then prevalent sociopolitical reality of segregation where inter-institutional contact in sport was not only a social taboo, but also condemned by the government. The participation of individual black athletes at so-called "white" meetings was highly irregular and officially discouraged at all levels, from club to national (Steyn 2015:17).

\section{BACKGROUND TO THE RESEARCH QUESTION}

The historic Rhodes-Fort Hare meeting has largely remained obscured in the history of South African sport. Yet, it was an extraordinary and significant event in local sporting historiography. The primary source material of this event - unearthed during research for a different project - shed light on a truly remarkable meeting within the political context of that time. The source material cast a captivating perspective on the courageous efforts of sports officials from

2 Three prominent statesmen and politicians were associated with athletics in the Eastern Cape during the 1930s to the late 1940s. Sir Seretse Khama (future President of Botswana), Y Luli (who succeeded Idi Amin for a short time as ruler of Uganda) and Robert Mugabe (President of Zimbabwe) all participated. Khama was an able shot-putter, Luli won the 800 metres in a fine $1 \mathrm{~min} 59,3 \mathrm{sec}$ and Mugabe took part in the 400 metres (LPPC 1946c:42). 
Rhodes University to normalise sporting relations, and on their attempts to extend a hand of reconciliation across the racial divide to the University of Fort Hare (Sport Express 1946b:10). ${ }^{3}$

In the source material there is evidence that, as early as during the 1930s, the so-called "black" tertiary institutions in the Eastern Cape had already displayed a vested interest in athletics. Encounters between these black institutions actually pre-dated the 1946 meeting, involving a cluster of entities based in the Eastern Cape region: Fort Hare University, Lovedale Missionary Institute, St Matthew's College (Keiskammahoek) and Fort Cox Agricultural College. The upswing in athletic activity emanated from pioneering groundwork on the part of coaches and the sound administration practised at these institutions. The development of athletics within the black student community peaked when the white university (Rhodes) decided to engage Fort Hare University in an intervarsity meet. This event provided the stimulus for the first South African Bantu Athletic Championship to be held in Pretoria in 1949.4 The formal and institutional development of a black sporting community in the Eastern Cape had the intrinsic potential to normalise sport at a national level. Potentially, the step up from club to national level had the ability to change the trajectory of sports and politics in the country, and to steer away from segregation on the field of play. However, continued and increased political interference after 1948 was destined to halt this promising development in the Eastern Cape by steering sport in a direction where it would have an adverse effect on athletes of colour, as well as their white counterparts, and invite international condemnation.

The significance of the meeting and other initiatives in the Eastern Cape during the 1930s to late 1940s was that these represented brave attempts on the part of white organisers and administrative officials to improve relations across the colour line by establishing interracial relations with the so-called "Bantu" colleges in the area. These initiatives resulted in the historic athletics meeting between Rhodes University and Fort Hare University on 23 October 1946; which will be discussed in this article as a case study. Importantly, the meeting casts light on a high-impact civil society initiative which, in the face of the national government's disapproval, attempted to normalise sport on a sub-societal level.

The era straddling the Second World War (1939-1945) displayed deep racial divisions in South Africa with profound institutional barriers being erected and maintained between the different race groups. In this highly regulated social context the administration and organisation of sport was instrumental in

3 In other sporting codes, like cricket, for example, Lovedale College in the Alice region established regular contact between black and white teams during the late $19^{\text {th }}$ century (Parry 2009:22 in Murray and Vahed (2009)). In athletics, however, interclub competition across the racial divide did not materialise before the historical 1946 meeting.

The first South African Bantu Athletic Championship took place under the auspices of officials of the Northern Transvaal Amateur Athletics Association at the Pelindaba Stadium, Atteridgeville, Pretoria. 
amplifying and reinforcing racial divisions. As Hall, Parry and Winch (2009:8-17) explain, the interrelationship between sport and politics during the apartheid era meant that the two domains were always interwoven and highly regulated. Sport in this regard formed part of a broader ideology aimed at ensuring that the imposed racial boundaries aligned with the policies of separate development in the country. The authors demonstrate how cricket was used from early on in South Africa to institutionalise segregation and, eventually, to reinforce segregation between white and black in the country. In this wider context sport was therefore used as an important additional instrument in concretising unequal power relations between white and black.

In South Africa, the separation between the various race groups occurred at all levels and was prevalent in all sporting structures. The national (Springbok) teams that participated in international events were drawn exclusively from the white community, while the black community was left out in the proverbial cold. At the domestic level interracial competition was highly irregular and regarded as a social taboo and, thus, formally and informally discouraged.

\section{A POLITICAL AND HISTORICAL BACKGROUND TO ATHLETICS IN SOUTH AFRICA}

In apartheid South Africa, prior to $1960,{ }^{5}$ sport was dominated and regulated by the broader socio-political context. The central government set up a broad sociopolitical framework but, despite this regulatory position, it was hesitant in officially formulating a sporting policy for the country. In the absence of such a policy, the government (indirectly and by proxy) dictated societal power relations and hence the policies that governed sport. The national sporting body that administered athletics, the South African Amateur Athletic Union (SAAAU), which was formed in 1894, regulated athletics in the various provinces and clubs. SAAAU officials ensured that the administration of athletics complied with local social customs and was aligned with the overarching ideology of separate development. The unfolding relationships, power structures and power relations between different race groups, and their participation at meetings, were thus dictated by social customs, rather than directly imposed by central government.

This development aligns with the Gramscian notion of hegemony, which is the ideological and cultural domination of one class over another, achieved by engineering consensus through controlling cultural forms (Jarvie 2006:29). This power relationship was essentially socially engineered in that control

5 The year 1960 is significant, as it represents the last time apartheid South Africa was allowed to compete in the Olympic Games. In the prelude to the Games, the government was compelled to reveal its official sporting policy, which inevitably led to its eventual banning and later expulsion from the respective international sporting federations (Allison 1986:115). 
was of paramount importance in establishing a system of informal separation during the foundation years of, what was later to become, an apartheid state (Sugden and Tomlinson 2002:9). As Hargreaves (1986:3) explains, the use of power in establishing relations between different classes and different agents was determined by the agent's access to relevant sources. Black communities were excluded from the various levels and structures of power and granted only limited access to resources. This lack of power put black communities on the back foot, forcing them to passively accept, for many decades, their alienation from, and lack of ownership of resources and the seats of power. It was only in the period 1960-1976, when the pressure which the international community exerted on the apartheid regime became an available resource, that black communities could apply pressure of their own through resistance movements aimed at righting imbalances in power and social relations; also in sport.

SAAAU provided leadership during the founding years of the National Party Government, but it was obvious from its focus, energy and resources that it predominantly aimed to benefit the white community. The minutes of the SAAAU's first meeting have not been preserved, but the first clubs that affiliated with the national body were all-white and had been constituted along the same lines. The first athletic clubs informally excluded black participation from the outset, setting a course which would ensure a divergence of paths between white and black (Le Roux 1985:7). In 1878, the Diamond Fields Advertiser reported the formation of the first athletics club north of the Orange River. With its all-white membership, the club provided insight into how athletics developed during the early years in South Africa. The Kimberley-based Diamond Fields Advertiser advertised a sporting event that specifically excluded black athletes. This position did not change; since in 1892 the paper reported that an athletics meeting had been organised for blacks at De Beers. This is evidence of clubs toeing the line of separate development by organising separate events for the different racial affiliations (Coghlan 1986:236).

Notwithstanding the official exclusion of blacks from participating in allwhite meetings, scattered reports continued to surface of individual blacks competing at white athletics events. It was reported in 1863 that, at a meeting on the Parade in Cape Town, a black athlete, Simeon, was placed second after W Day in the 880 yards sprint. In Port Elizabeth events for black athletes were included at a few meetings reserved for whites. At one such meet Makwena won the mile in 4 min $53 \mathrm{sec}$ - one second faster than Jim Brown's time in the first South African Mile Challenge in 1885. In East London there were reports on a native championship in 1894, with the most notable performance being that of Peter Dalaze who won the 880 yards in 2 min 14,2 sec (Steyn 2015:17). 
The first all-white South African Athletics Championship, held in Kimberley in 1894 , was by all accounts a very successful meeting (SAAAU minutes ${ }^{6}$ ). On the second day of the championship, a three-mile cycle race for coloureds was included in the programme, but this was the only allowance made for non-white participation at the national championships (SAAAU minutes).

From the outset the official objective in sport was undeniably to "encourage" black and coloured participants to form their own (separate) clubs. These communities duly obliged and the Colonial Athletic Club for coloureds was formed in 1895 in Kimberley. The club allowed blacks to join, but disagreements quickly surfaced among the various groups about representation at a national level (Coghlan 1986:236). The Western Province Coloured Amateur Athletics and Cycling Union was formed a few years later, with its inaugural meeting at Green Point in 1902 (Steyn 2015:17). However, the SAAAU as national controlling body quickly squashed any participation by these clubs at a national level. The 1896 South African Athletics Championship led to a complaint against the possible participation of "Kaffirs" [sic] ${ }^{7}$ and the idea of including non-white competitors was dropped.

The administration and organisation of black athletics in the Free State developed along similar lines as its white counterpart, with non-white meetings held separately from white meetings. The first reported meeting for blacks in the Free State took place in 1886, when a native sports day with athletics items on the programme was held at the St Augustine Mission Station. There were reports of the Free State Athletic Union organising a meeting on its Independence Day in 1885 and, according to The Friend, it included a "Kaffir" [sic] race (Coghlan 1986:235).

In South Africa, control over social relationships in all other regions followed a similar trajectory to that in Kimberley and in the Free State. However, the uniformity of the system to separate races within an integrated society was not without its challenges, despite isolated evidence of continued participation by black individuals. The 1904 South African Championships, held at the Wanderers Track in Johannesburg, attracted its fair share of controversy: the proposal to include events for blacks was hotly debated and eventually withdrawn. The Orange River Colony Athletic Association and Cycling Association enquired from SAAAU about the possibility of blacks participating at athletic meetings. The national body discussed the matter at its 1904 meeting under the item, "Native Competition", and reported back that no rules existed in this regard, but that provinces should refrain from including such races in future programmes (SAAAU minutes).

\footnotetext{
6 The minutes of the South African Amateur Athletics Union (SAAAU) are included in the publication by Le Roux (1984).

7 It is accepted that the word is derogatory, but it is functional within this context.
} 
The controversial issue of racial integration in sport, and the participation of blacks in meetings, kept creating problems in the early decades of the $20^{\text {th }}$ century. In Johannesburg controversy kept surfacing as a result of coloureds attending sports meets. The advice forthcoming from the SAAAU to the provinces and clubs was that the time was not ripe to allow people of colour to attend or participate in such competitions (Coghlan 1986:235).

The early organisation and administration of black and coloured athletics in South Africa therefore yielded to a single inference: politics. Having nonwhites compete against whites, or participate at white-organised meetings, was discouraged because it transgressed the social "rules" of the era (Coghlan 1986:235; Steyn 2015:115). Regulatory measures were basically enforced by those in power with the solitary aim of establishing a social hierarchy based on the strict separation of races. As indicated earlier, this strategy aligns strongly with the Gramscian notion of hegemony where the ideological and cultural domination of one class over another is achieved by engineering consensus through taking control of all cultural forms (Jarvie 2006:29). The foundation years of athletics in South Africa therefore witnessed power being wielded by controlling social relationships; thereby aiding an informal system of separate development (Sugden and Tomlinson 2002:9).

\section{THE DEVELOPMENT OF INTERVARSITY SPORT - MORE OF THE SAME}

Participation in intervarsity athletics meetings in South Africa was strategically and formally perpetuated along racial lines. The intervarsity athletic competition between the various universities (Dalrymple) was held for the first time in 1921. Although this annual intervarsity had a modest start (initially only four universities participated), the magnitude thereof soon expanded to include almost all white universities. However, the amicable spirit of friendly cooperation at these intervarsities suffered a setback when political overtones crept into the overall structure of sport. Politics and racism began to interfere in sport, and their impact on athletics saw the Dalrymple Competition organisers threatening to put an end to the annual meetings (Joubert 1985:40-57).

When the South African Parliament in 1939 decreed that the country would participate in the Second World War, it created a division in relations between the various universities. The subsequent disputes that followed the decision tore universities apart along language and political lines. The Afrikaans universities decided to withdraw from the National Union of South African Students (NUSAS) and they formed their own body, the Afrikaanse Studentebond (ASB). The universities of Pretoria, Potchefstroom, Bloemfontein and Stellenbosch subsequently established the Studente-atletiekbond and organised an athletics meeting between the break-away group of universities. The Afrikaans 
universities' numbers were bolstered by the teachers' training colleges, and the group held annual athletics competitions without their English counterparts (Van der Merwe 1985:53).

At the 1946 Dalrymple Meeting only the four English-speaking universities (Cape Town, Rhodes, Natal and Witwatersrand) participated, which essentially resulted in a watered-down competition. Sporting officials undertook a joint initiative aimed at healing the rift between the universities and, while the Afrikaans universities were prepared to negotiate, they set out specific preconditions for their return to the fold. Two of these demands were not unreasonable and related to the inclusion of the teachers' training colleges and the participation of female athletes in future meetings. However, the third formed a stumbling block, because the Afrikaans universities insisted that there should, in future, be a strict adherence to the colour bar. However, this demand was allowed to gradually drift into the background over a period of time and, as a result, the full complement of universities competed at the 1947 Dalrymple Meeting (Joubert 1985:57).

Such racial compartmentalising meant divisions between the universities remained intact. However, this unsatisfactory position was about to be challenged with the occurrence of a watershed incident during the same period. The Captain and the Honorary Secretary of the Rhodes University College Athletic Club, MD Miller and SN Mandy, were instrumental in launching a unique venture across the racial divide between two racially divided universities. Miller and Mandy referred in their letter to the Sport Express (1946b) to the then existing sociopolitical status quo as the, "controversial position on Natives in sport". The two student leaders took the initiative to organise a multiracial meeting in order to break the political impasse. They deemed the meeting - between a white university (Rhodes) and a black university (Fort Hare) - to represent a "more enlightened and constructive" policy; a statement presumably made in respect of the national policy of separation in sport (Sport Express 1946b:10). While the Rhodes University Athletic Club initiative represented a brave effort to normalise sport and to level the playing field, it clearly contravened the strict segregationist policy of government.

Any discussion of the historic Rhodes-Fort Hare match should take cognizance of the overall status of athletics in the Eastern Cape during the era preceding the meeting. The discussion in the next subsection provides some background on the level and status of athletics at black institutions in that province during the late 1930 s and the 1940s.

\section{THE STATUS OF ATHLETICS AT BLACK COLLEGES}

ML Macquarrie, a lecturer at the Lovedale Missionary Institute during the 1920s and 1930s, kept personal notes which have proven invaluable in granting important insights into athletics in the Eastern Cape region. A broader context 
appears in the recorded history of Fort Hare in Alexander Kerr's Fort Hare 19151948 (1968), which contextualises developments and offers a captivating look into the status and level of athletics at black colleges and institutes. Fort Hare, Lovedale Missionary Institute, St Matthew's College (Keiskammahoek) and Fort Cox Agricultural College were all situated in relative close proximity to one another, and were probably at this junction the only black tertiary institutions to have adopted an athletics programme for their students.

Macquarrie writes that, on his arrival at Lovedale College in 1924, he discovered that an annual athletics meeting was regularly held on Victoria Day (24 May). He observed, however, that there was no preliminary or preparatory training for the meeting. The athletics programme on the day made provision for most sporting codes, but did not include certain field events, such as discus and javelin. The programme did, however, include non-athletic events such as tug-ofwar and cricket ball throwing (LPPC 1946c:22).

The athletics culture and level of sporting development at black colleges and institutions were not up to standard, but the students' lack of training and skill was made up for by their sheer enthusiasm. Officials at the meeting had to cope with spectators swarming onto the field or crowding around the field events. Some spectators even ran alongside the athletes in the middle distances, offering encouragement and advice. The officials, too, were not professionally trained: there was evidence of a white official in the early 1950s measuring the long jump from the wrong side of the board (Kerr 1968:111; LPPC 1946c:22).

Several athletes of the Lovedale Missionary Institute displayed a level of resistance to higher standards of training and, in some instances, feared technical changes. Macquarrie writes that sprinters were skeptical about adopting the latest developments, such as starting in the crouch position. The black students also declined to use spiked running shoes, believing that the spikes would keep them stuck to the track. There was significant resistance to the firing of a starter's pistol, even when it was explained that blanks, rather than real bullets would be used. Given the political environment of the time, it was hardly surprising that, "they did not trust a white man with a pistol standing behind them and firing it" (LPPC 1946c:22).

Soon the efforts of the coaches and officials at the black institutions started to pay off, and it was during this period that athletics slowly gained a foothold in the Eastern Cape. The more focused attention developed into better performances and, eventually, materialised in inter-college and interinstitute meetings. The first competition of this kind was held on 27 April 1923 between Fort Hare, Lovedale Missionary Institute, St Matthew's College (Keiskammahoek) and Fort Cox Agricultural College (Kerr 1968:111). Although the athletes of Fort Cox were the least coached of all the participating teams, their athletes were competitive, because they had the added advantage of doing 
manual work as part of their studies, and this had made them stronger than the other students.

The historic meeting between the black institutions took place at the St Matthew's Stadium and the competing teams were Fort Hare, Lovedale, St Matthew's and Healdtown. The principal of Lovedale, Dr RHW Shepherd, declared afterwards that, "more records were broken (here today) than at any other meeting of this type" (Sport Express 1923).

The outstanding athlete at the meeting was Manana ${ }^{8}$ of St Matthew's, who recorded a fast $9,9 \mathrm{sec}$ in the 100 yard dash and $21,7 \mathrm{sec}$ in the 220 yards. In the press, the success of the meeting was hailed as an encouragement to those interested in African athletics to help form an African Amateur Athletic Association (Sport Express 1923).

\section{THE RHODES VS. FORT HARE MEET - SOME PERSPECTIVES}

The South African government's segregationists and discriminatory policies during the decades that followed the Second World War evoked international condemnation and eventually led to its expulsion on all levels. The International Olympic Committee (IOC) and the International Athletics Federation (IAAF) were forced, after decades of failed and futile negotiations, to terminate South Africa's membership (Le Roux 1985:110).

The insistence on racial separation was so persuasive that it even impacted on the composition of international teams visiting the country. The petty apartheid laws that progressively appeared on the law books made it impossible for an American team visiting South Africa to include their strong AfroAmerican sprinters. It was therefore not surprising that the US track and field teams that toured South Africa in the 1940s consisted solely of white athletes (Joubert 1985:45).

The Rhodes and Fort Hare meeting was conceived against the background of the 1946 split between the English universities and the Afrikaans universities, when the latter broke away from NUSAS to form their own unit. The climate was now conducive to an alternative approach to inter-university sport. The decision by the administrators at Rhodes to look for a local alternative was a direct result of the split. The result was a locally based intervarsity against Fort Hare, which proved to be a rational and logical decision on more than one level: their locality and geographical proximity made transport and funding problems negligible. On a political level, the Rhodes University athletics officials were clearly not prepared to toe the official party line and were determined to breach political barriers.

$8 \quad$ No initials were provided. 
When analysing the results, it is obvious that the general standard amongst the black athletes of Fort Hare was competitive. In the 100 yards, D Tiso of Fort Hare won in 9,9 sec and recorded a time of 22,4 sec in the 220 yard dash. Tiso managed to beat Dennis Hassenjager of Rhodes University into second place in both events. The fact that Hassenjager was a top athlete in South Africa, who had received national (Springbok) colours in 1950, puts Tiso's performance in perspective (Le Roux 1985:29). While Hassenjager went on to achieve national colours three years later, Tiso's career as a result of petty politics was sadly allowed to slip into oblivion.

Nyati ${ }^{9}$ of Fort Hare won the long jump with a distance of 21 feet 1,5 inches, while Mazwana won the two-mile race in a creditable time of 10 minutes 5,4 seconds. Although Fort Hare was beaten in the overall points competition, its athletes did extremely well in their first outing against an experienced opponent. The final outcome of the competition was Rhodes 80 points, Fort Hare 36, but on a social level the meeting was memorable for more than just the competitors' athletic prowess.

On the surface, the meeting was important because it improved the standard of athletics and helped consolidate and develop athletics in the Eastern Cape. The important resulting impact was that it represented a valiant effort on the part of civil society to bridge the politically constructed racial divide between population groups. However, despite this positive step, the local paper, the Sport Express on 6 November was critical and stated in an editorial that the organisers of the meet should have taken "wider issues" into consideration before organising such an event (Sport Express 1946b:14). The wider issues that the newspaper referred to in its editorial are certainly the overarching racial policies of the government and its aim to keep the races segregated.

Miller and Mandy had to defend their actions in the press after this intervarsity and they reacted to the negative slant taken by the paper. The two argued that their efforts were motivated by the desire to benefit sport. In a letter to the newspaper, they explained that the meeting was meant to be a countermeasure against the negative political policy of separation (Sport Express 1946b:10). They expressed their concern regarding the generally controversial policies towards natives in the country and labelled the meet as an "enlightened and constructive" step. They also pointed out the international ramifications of a failure to make progress in normalising sporting relations in the country; such measures would include boycotts (the American team would, for instance, not be "allowed" to compete in South Africa, because it featured black sprinters). Miller and Mandy argued that the "white superiority" at the basis of segregation had to be based on something more meaningful than divisions in sport. The two Rhodes students also made the point that universities are there to lead, not to be subservient to public opinion (Sport Express 1946c:14).

In the results, no initials were provided for some of the black athletes. 


\section{CONCLUSION}

Having made the point that complete segregation between the various races in South Africa was not possible, Miller and Mandy argued that a non-contact sport, such as athletics, should be permissible between the different race groups (Sport Express 1946b:14). However, despite these student leaders' enlightened and progressive views, their statement revealed the pervasive effect of apartheid ideology on their good intentions. Their "enlightened" view was tainted with a nuanced perspective on integration when they suggested that non-contact sports (such as athletics), rather than contact sports between the different race groups, should be permissible.

When analysing the historic 1946 intervarsity between a white institution and a black institution after so many decades, the meeting seems rather trivial, insignificant and even inconsequential. Efforts by Rhodes University to challenge local segregation customs seem trifling and lacking in substance to effectively challenge the then prevailing sentiments. The meeting in itself was not substantial enough to impact on the apartheid structure, or the laws that were forming around them.

The contact that resulted from the athletics meeting was restricted to the different race groups represented in a cluster of tertiary colleges and institutes in the Eastern Cape. On a higher level, the Dalrymple Intervarsity Athletics Championships continued unaffected, and over the years grew exponentially into a major competition between white universities. The significance of the Rhodes-Fort Hare meeting was dwarfed by the sheer magnitude of the Dalrymple events. Black universities thus remained isolated and out in the cold, while white universities flourished during the 1960s to 1980s. It took decades (as late as 1986) before the University of Zululand (UZ) was invited to compete against white universities at this prestigious level. However, this ill-conceived attempt was a case of too little, too late. The level of performance at this topclass competition highlighted the huge performance gap, and left the UZ trailing embarrassingly far behind its white counterparts (Joubert 1985:89).

In spite of courageous efforts by members of civil society, the administration and development of sport (athletics) in South Africa became more segregated and progressively more guarded. In the face of international condemnation, politicians and athletic administrators retreated further into a shell of regressive segregationist policies. The international community was predictably not prepared to accept South Africa's discriminatory policies and continued to put pressure on the government to officially state its sporting policy. The government at that stage was not progressive enough to comprehend that its participation in the Olympic Games of 1960 was under threat. It continued to insist on, and defend a policy of racial separation, remaining adamant that no racially mixed teams would be selected for the Games. This decision and inflexible stance 
sounded the death knell for South African athletes in terms of their continued participation in the international arena (Allison 1986:111).

South Africa's expulsion from the two major international sporting federations (the IOC and the IAAF) and all international events set the country on a lonely path towards complete isolation. Regardless of courageous efforts in the 1980s by SAAAU to normalise athletics, the international goalposts for readmission had shifted. No longer was the demand for fully integrated teams picked on merit; it was for much more substantial political and social change in the country before the international sporting fraternity would be prepared to welcome South African teams back into the fold (Killanan and Rhoda 1979:115).

Thus, although the significance of the Rhodes-Fort Hare athletics meeting was probably negligible and insignificant within the broader context, the attempt to stage a memorable competition on a bumpy track in October 1946 should at least be applauded and celebrated after all these years. It is true that profound changes in history are indeed made by high-impact incidents, but smaller, courageous events which challenge immoral and illogical manifestations in society, also deserve a large measure of credit.

\section{LIST OF SOURCES}

Allison, L 1986. The politics of sport. Manchester: Manchester University Press.

Allison, L 2005. The global politics of sport: The role of global institutions in sport. London: Routledge.

Arlott, J 1968. D'Oliveira: An autobiography. London: Collins.

Bairner, A 2005. Sport, nationalism and globalization: European and North American perspective. Albany: State University of New York Press.

Coakley, J 2002. Sport in society: Issues and controversies, $9^{\text {th }}$ edition. Colorado Springs: McGraw Hill Publishers.

Coghlan, D 1986. The development of athletics in South Africa 1814-1914. PhD, Rhodes University.

Grundlingh, AM 1995. Beyond the try line: Rugby and South African society. Johannesburg: Ravan Press.

Hall, B, R Parry and J Winch 2009. In: B Murray and G Vahed (eds), Empire and cricket: The South African experience, 1884-1914. Pretoria: Unisa Press.

Hargreaves, J 1986. Sport, power and culture. Cambridge: Polity Press. 
Hartmann, D 2004. Race, culture and the revolt of the black athlete: The 1968 Olympic protest and its aftermath. Chicago: University of Chicago Press.

Houlihan, B 1997. Sport, policy and politics: A comparative analysis. London: Routledge. https://doi.org/10.4324/9780203288955

Jarvie, G 2006. Sport, culture and society. London: Routledge.

Joubert, A 1985. The history of intervarsity sport in South Africa. Durban: South African Universities Athletics Association.

Kerr, A 1968. Fort Hare 1915-1948: The evolution of an African College. Pietermaritzburg: Shuter and Shooter.

Killanan, M and J Rhoda 1979. The Olympic Games. Oxford: Oxford University Press.

Korr, C and M Close 2008. More than just a game: Soccer vs apartheid. London: Harper Collins Publishers.

Labuschagne PAH Private Collection (LPPC).

1946a. Programme of the Annual Inter-Institution Athletic Sport, held on 27 April at St Matthew's College Stadium.

1946b. Handwritten results of meeting, 23 October.

1946c. Personal notes of ML Macquarrie, Lovedale Missionary Institute.

Le Roux, G 1985. Golden years/goue jare. Pretoria: Henkos Drukkers.

Murray, H and D Vahed 1998. Empire and cricket: The South African experience 1884-1914. Pretoria: Unisa Press.

Nauright, J and D Booley 1998. Rugby and the South African nation: Sport, culture, politics and power in the old and new South Africa. Manchester: Manchester University Press.

South African Bantu Athletics Championship 1949. Programme of Championship held at the Atteridgeville Stadium, Pelindaba, 3 October.

Sport Express 1923. April 29.

Sport Express 1946a. October 23.

Sport Express 1946b. November 6.

Sport Express 1946c. November 23. 
Steyn, D 2015. History of South African cross-country, middle and long distance running and walking, 1894-2014, Volume 1: 1894-1966. Pretoria: Group 7.

Sugden, JP and A Tomlinson 2002. Power games: A critical sociology of sport. London: Routledge.

Van der Merwe, F 1985. Honderd jaar van Matie-atletiek, 1885-1985. Kaapstad: CTP Boekdrukkers.

Wallechinsky, D 1984. The complete book of the Olympics. London: Penguin. 